\title{
Preparation and Characterization of Eco- Friendly Ash Salts for Goat Skins Preservation
}

\author{
Franco John Unango, Ramesh Duraisamy, Karthikeyan M. Ramasamy
}

\begin{abstract}
Worldwide, mostly skin is preserved using $\mathrm{NaCl}$ which is polluting the environment by increasing soil salinity, affecting water body, releasing of more than $40 \%$ TDS and $55 \%$ $\mathrm{Cl}$. In the current study, plant derived ash salt from Acacia albida and Acacia bussei was used as salt-less and less salt formulations for curing goat skins, proving effective alternative to the conventional preservation with $\mathrm{NaCl}$. Ash salt was prepared by burning the plants' stems and leaves completely into ashes, soaked in water and then filtering; then boiling to evaporate water to get an ash salt. The ash salt demonstrated better antibacterial properties in preserving goat skins for $21^{\text {st }}$ days without disintegration. Moisture contents were reduced to less than $30 \%$, nitrogen content and bacterial counts were sound and stood in a normal unaffected range and preserved skins were later processed and chrome tanned into crust upper leather. The physico-mechanical and chemical properties of all crust leathers were tested and the results met the standard requirements. The shrinkage temperatures (Ts) of all the prepared and preserved goat leathers were shown to be above $90{ }^{\circ} \mathrm{C}$. Organoleptic properties were also analyzed and were shown much better. The pollution loads of soaking liquors were assessed and there was dramatic reduction in levels of total solid, total suspended solids, chloride, total dissolved solid, biochemical oxygen demand and chemical oxygen demand released along with the wastewater with the significant variations $(P>0.05)$.
\end{abstract}

Key terms: Putrefaction, Moisture content, Ash salt, goatskin, Pollution, preservation, Collagen.

\section{INTRODUCTION}

Skins which are the byproducts of meat industry are the actual raw materials of the leather industry. Few hours after animal flayed, skin falls vulnerable due to bacteria assault in case it is not well cured. Proteins of the skin are the main inviter of bacteria and it is only through curing that the raw stock can resist disintegration and reserve leather quality [1].

The scanned literature revealed that the main components of fresh skin are moisture (60-70\%), proteins (25-30\%), fats $(2 \%)$, carbohydrates and mineral ingredients constitute (1\%). This huge amount of moisture let bacteria to double in their numbers in less than 4 hours at $25{ }^{\circ} \mathrm{C}$ whereby the bacteriamyales may has serious grain peeling and voids in the skin from 15-24 hours [2]. The standard salt curing method for skins allowed $40-50 \%$ sodium chloride to be used in preservation based on its dehydrating power and bacteriostatic property that can reduce moisture content

Revised Manuscript Received on September 10, 2019.

Franco John Unango, Department of Chemistry, College of Education, University of Bahr El Ghazal, Wau, South Sudan, North Africa. Department of Chemistry, College of Natural Sciences, Arba Minch University, Arba Minch, Ethiopia, East Africa.

Ramesh Duraisamy, Department of Chemistry, College of Natura Natural Sciences, Arba Minch University, Arba Minch, Ethiopia, East Africa. Sciences, Arba Minch University, Arba Minch, Ethiopia, East Africa.

Karthikeyan M. Ramasamy, Department of Chemistry, College of

from $70 \%$ to $30 \%$ making the condition of the skin nonconducive for bacterial growth [3]. Though the method is cost effective and easy to practice; it was evaluated that nearly 3 million tons (annually) of untreated salt are been discharged during first unit processing of leather and this leads to significant contribution of salinity to the soil [4], affecting water body, facilitate soil erosions and released of more than $40 \%$ of TDS and about $55 \%$ of chlorides in soaking liquors [5]. The responsibility of searching new alternatives to table salt curing method becomes an obligation for all researchers in the field of leather technology. As per review of literatures, there have been several initiations deviating from chemicals to the most reliable one (plant based preservation) such as the used of herbal Rumex abyssinicus (mekmeko) roots, for preservation of goat skins [6], the antimicrobial properties of de-oiled neem cake extract against the microbes and its effect of preservation [7], application of Moringa oleifera leaf paste in combination with lower salt on the goat skin [8], less salt preserving systems based on herbal extract [9], the use of Clerodendrum viscosum leaf paste combination with lesssalt [10], Acalypha indica leaves paste [11], and many others.

Earlier review on the current status of hides/skins preservation systems ranging from chemicals to organic preservatives were also reported [12] as; less $\mathrm{NaCl}$ curing methods: (SC + EDTA, SC + silica gel, SC + sodium metabisulphite and $\mathrm{SC}+$ boric acid). $\mathrm{NaCl}$ free methods (Inorganic preservatives): ( $\mathrm{KCl}, \mathrm{NaSO}_{4}$, silicate and ozone). Physical preservative methods: (electric current, chilling and vacuum) and organic preservatives (the current emphasis): (paste plant formulations, essential oils, chlorophyll and bacteriocins).

The word Ash referred to the residue left over after the burning of organic/plant materials. Previously, ash was known as "Potash" from two words potassium-ash. This was because potassium is considered the main alkali metal in the ash. Salts originated from plant ashes have been reportedly used in tropical Africa, North and South America. These salts obtained from plant ashes are called "Ash Salts" (Vegetable salts or wood salts) [13]. It is also commonly known as "Kombo" in Sudan and South Sudan.

Today in Africa, ash salts are still been produced traditionally and used for businesses, consumption by communities, performing religion practices, an alternative to white salt $(\mathrm{NaCl})$ for therapeutic reasons (icterus, to lower the blood pressure, as sedative against cough, etc.) [14]. 
There was no more information accessed about the use of ash salt in leather technology, but instead ashes have been reportedly used to prevent the growth of microorganisms on fruits, meats and others.

This study was an attempt to introduce new cleaner technology of preservation of skins by using eco-friendly ash salt that is derived from the ashes of Acacia albida and Acacia bussei of fabaceae's family plant.

\section{EXPERIMENTATIONS}

\subsection{Materials}

\subsubsection{Goat Skins}

Two freshly flayed goat skins of an estimated green weight $1 \mathrm{~kg}$ per each were procured from a local area in Arba Minch town, Ethiopia.

\subsubsection{Table salt}

Commercial grade sodium chloride $(60 \%)$, white colour was purchased from local market and it was used in the study.

\subsubsection{Ash Salt Preservatives}

About $15 \mathrm{~kg}$ of the burned plant ash was taken. Half of small container served as filter was filled with ashes and was kept on top of the big container with a supporter on the base to avoid falling in. Water was poured on the ash and it was soaked in water and after few minutes it started leaking out through the pores/holes in the bottom of the small container. The filtrate was collected and heated to boiling until most of the water got evaporated and the semi liquid (sludge) remains and was kept down to dry, and it was then characterized before used in the study as new preservative [15].

\subsection{Methods}

\subsubsection{Experimental Design for Preservation}

Each of the two freshly flayed goat skins purchased was cut into two halves along the backbone to avoid skin variation. One left sided skin was treated as control $(\mathrm{NaCl})$ and its pair right sided was used for ash salt (II). The other left and right sided skins were employed for sample III and IV respectively, details of design was shown in Table 1.

All percentages of preservatives were based on green weight and were applied manually on the flesh sides of the skins, then were folded flesh to flesh, rolled and kept for preservation at an ambient temperature $26-32{ }^{0} \mathrm{C}$ for 21 days. The effectiveness of the curing was monitored periodically from fresh onwards as Fresh, $4^{\text {th }}$ days, $7^{\text {th }}$ days, $14^{\text {th }}$ days and $21^{\text {st }}$ days of preservation in terms of hair slip, bad odour, and mucous surface, moisture content, nitrogen content and bacterial colony count [16].

After 21days, the preserved goatskins were taken for soaking and processed into upper crust leather.
Table 1. Experimental Design for percentages and blend of the preservatives offered.

\begin{tabular}{llll}
\hline S/No & Sample code & $\begin{array}{l}\% \\
\text { preservatives offered }\end{array}$ \\
\hline 1. & I (control) & $50 \% \mathrm{NaCl}$ \\
2. & II & $50 \%$ ash salt \\
3. & III & $10 \% \mathrm{NaCl}+40 \%$ ash \\
& & salt \\
4. & IV & $15 \% \mathrm{NaCl}+35 \%$ ash \\
& & salt \\
\hline
\end{tabular}

\subsubsection{Determination of Moisture Content}

About $2 \mathrm{~g}$ were weighed from control and experimental samples, unhaired using razor blade, dried in hot air oven at $105{ }^{\circ} \mathrm{C}$. Then, cooled in desiccator for 20 minutes and reweighed, then calculated [17].

\subsubsection{Estimation of Total Nitrogen}

About $5 \mathrm{~g}$ of cured skin was cut, washed with distilled water then kept in a bottle for 3 hours rotating at $35 \mathrm{rpm}$ using rotatory shaker. It was then filtered and digested in 15 ml of conc. $\mathrm{H}_{2} \mathrm{SO}_{4}(96 \%)$ with the help of catalyst, then taken for distillation and finally back titrated the excess ammonia using $0.05 \mathrm{M} \mathrm{NaOH}$ according to Total Kjeldahl Nitrogen method [18].

\subsubsection{Evaluation of Bacterial Count}

$5 \mathrm{~g}$ of sample was taken and soaked in $50 \mathrm{ml}$ of sterilized water, shake by orbital shaker at $200 \mathrm{rpm}$ for 30 minutes. Then filtered and $1 \mathrm{ml}$ of filtrate was diluted to $10 \mathrm{ml}$ with sterilized water. $1.0 \mathrm{ml}$ of the diluted solution was taken into the sterilized petri dish containing molten nutrient agar and was incubated at $37{ }^{\circ} \mathrm{C}$ for 48 hours [19].

\subsubsection{Physical Characterization of Leathers}

The physical properties of the crust upper leather were assessed according to [20]. The experimental samples and control for all leathers were conditioned for 48 hours at temperature $21.8^{\circ} \mathrm{C}$ and $\mathrm{RH} 62.5 \%$, and then measured the physical properties with respect to tensile strength; tear strength, elongation at break and thickness. The results of the study samples were compared to control and are shown in Table 4.

\subsubsection{Determination of the Shrinkage Temperature}

Specimens of leather $(50 \mathrm{~mm} \times 2 \mathrm{~mm})$ were cut along and across the backbone from the chrome tanned leather. Holes were punched at each ends of the sample to allow it to be held vertically in the test chamber. The equipment was closed and water is heated to boiling at $100{ }^{\circ} \mathrm{C}$ by external heat source. The temperature at which the leather started to shrink was noticed as the shrinkage temperature [21].

\subsubsection{Chemical Analyses of the Crust Leather}

The chemical analysis of the crust upper leathers of experimental samples and control were determined regarding the moisture content, oils/fats content, ash content 
and water soluble matters using official method [22]. The results were analyzed are depicted in Figure.3.

\subsubsection{Pollution Loaded in Soaking Liquors}

The liquors of soaking were collected and analyzed in terms of parameters such as biochemical oxygen demand (BOD), chemical oxygen demand (COD), total dissolved solids (TDS), total suspended solids (TSS), total solid (TS) and chlorides $\left(\mathrm{Cl}^{-}\right)$. The experiments were carried out according to official procedure [23] and the data were expressed in average values of triplicate measurements.

\section{RESULTS AND DISCUSSIONS}

\subsection{Qualitative and Quantitative Analyses of Ash Salt} (new preservative)

The qualitative test was targeting carbonates or bicarbonate salts in the sample using acid-base method. The effervescence of the gas was observed during the reaction suspected to be carbon dioxide, which confirmed the presence of either carbonates or bicarbonate in the sample with $\mathrm{pH} 12$ (strong alkali). The flame test also confirms the presence of sodium or

metal of ionic salts in the study sample through yellow color observed in burning.

Acid-base titration method signified the amount of $\mathrm{Na}_{2} \mathrm{CO}_{3}, \mathrm{NaHCO}_{3}$ and other neutral components obtained from $2.5 \mathrm{~g}$ of the sample taken to be $1.1 \mathrm{~g}(44 \%), 0.591 \mathrm{~g}$ $(23.6 \%)$ and $0.809 \mathrm{~g}(32.4 \%)$ respectively. The flame atomic absorption spectroscopy also confirmed the amount of sodium $(0.76 \pm 0.01)$, calcium $(1.71 \pm 0.10)$, magnesium $(9.28 \pm 0.50)$ and potassium $(17.20 \pm 0.65)$ present in ash salt. The moisture content, dry matter and ash content of the prepared ash salt were determined and the obtained results were $2.2 \pm 0.10 \%, 97.8 \pm 0.65 \%$ and

$97.58 \pm 0.60 \%$ respectively.

\subsection{Physical Evaluation of Preservation Efficacy on Goat} Skins

The merit of preservation was evaluated organoleptically by observing any of hair slip, emerging of bad odour and mucous surface of the preserved skins. The appearance of odor of ammonia gas, mucous surface and hair loosening are considered as initiations of putrefaction; and these facts were taken as measures for assessing the efficacy of curing the skin protein. The new preservative (ash salt) and its formulations with sodium chloride were able to preserved goat skins with no signs of degradation that observed in all cases of the preserved skins (control and samples) throughout the study during 21 st days of preservation (see Table.2).

Based on the results, ash salt alone or blended with less table salt are capable of preserving the goat skins as well as hides for more than a month.
Table 2. Evaluation of Preservation effectiveness of ash salt on Goat skin in 21st days

\begin{tabular}{|l|l|l|l|l|}
\hline \multirow{2}{*}{$\begin{array}{l}\text { Evaluation of } \\
\text { degradation }\end{array}$} & \multicolumn{4}{|c|}{ \% preservative materials offered } \\
\cline { 2 - 5 } & I & II & III & IV \\
\hline Hair slip & No & No & No & No \\
\hline Odor & No & No & No & No \\
\hline $\begin{array}{l}\text { Mucous } \\
\text { surface }\end{array}$ & No & No & No & No \\
\hline Putrefaction & X & X & X & X \\
\hline $\begin{array}{l}\text { Physical state } \\
\text { of skins }\end{array}$ & $\begin{array}{l}\text { standard } \\
\text { hard }\end{array}$ & $\begin{array}{l}\text { standard } \\
\text { hard }\end{array}$ & Flexible & Flexible \\
\hline
\end{tabular}

\subsection{Moisture Lost from Skins during Preservation}

The moisture content of skin is considered a central display that provides conducive environment for bacteria and other microorganisms to grow and feed on the skin proteins; consequently degraded the fresh skins which result in the poor quality of leather.

The appraisal of moistures reduction by ash salt and its fusions with less $\mathrm{NaCl}$ have shown that the moisture contents of the preserved skins decreased substantially to capitulated better preservation (Figure 1). This is due to diffusion mechanism of salt and ash salt through osmotic diffusion.

The samples (II, III and IV) and control (I) shown the excellent total percentage reduction as moisture contents decreased from total of 65 to $27.4 \%, 65.8$ to $28.6 \%, 70$ to $35 \%$ and 65.2 to $36.8 \%$ by SC, AS, SCAS-I and SCAS-II respectively during 21 days of preservation of present studied on goat skin. This shows that both salt and ash salt have been an excellent dehydrants.

The major moisture lost was demonstrated between $7^{\text {th }}$ days and $14^{\text {th }}$ days by II (15\%) against control I (15.6\%). The skins were preserved by III and IV also shown their highest moisture lost observed as $13.1 \%$ and $11 \%$ respectively, in the same period $\left(14^{\text {th }}\right.$ days $)$. The ability to reduce moistures from the fresh goat skins got decreased with increased in the percentage concentrations of $\mathrm{NaCl}$ to the ash salt (III to IV) and this may be due to available potassium in the ash salt has a chemical effect on the carbonate compound by accelerating its decomposition [13].

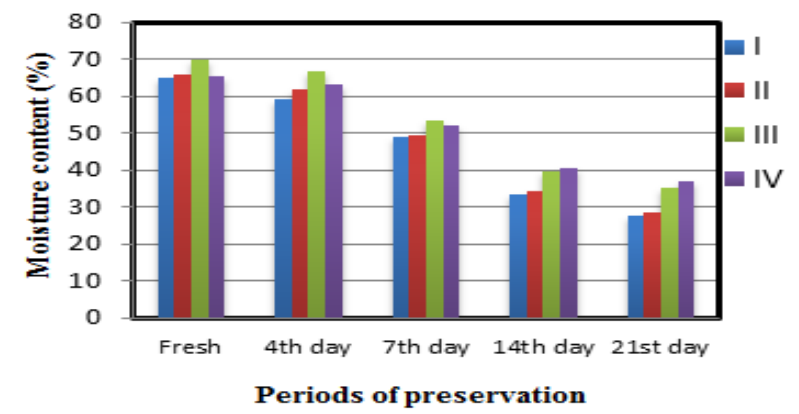

Figure1. The graph had shown the effectiveness of ash salt and its combinations in reduction of moistures from the study samples. $[\mathrm{SC}=$ Sodium chloride and AS = Ash salt]. 


\subsection{Total Nitrogen of Skins}

Total nitrogen is another indicator of putrefaction of skins. It is due to the releases of ammonia, which is formed when decomposition of proteins begins because of the action of bacteria. The total nitrogen content for both control and experimental skins at different time span were determined.

The plotted (Figure.2) clearly indicated that the observable increased the amount of nitrogen started from fresh towards day 4 was seen in III and stocked

After one week (stationary phase) in comparison to I. This is because the preservative was concentrating only on removing water from the skin but later acts as an inhibitor on bacteria population.

In IV, there was a gradual increase in nitrogen content in the first seven days and finally increased progressively from day seven to the highest $(3.48 \mathrm{~g} / \mathrm{kg})$ in 21 days of preservation against the corresponding control $(3.00 \mathrm{~g} / \mathrm{kg})$.

This may be because the experimental sample IV left bacteria intact and only based on its action about moisture removal rather than being static or biocidic compared to control (I) which involved in both inhibiting bacteria and moisture removal.

Experiment II performed much better, means it has admirable antibacterial effect (biocidal effect) and also good at moisture removal compare to control (I) which is having less antibacterial effect (biostatic effect) and better at moisture removal.

According to [24], male goat skins have fewer fats, more proteins (nitrogen) and have higher moisture contents than female goatskins.

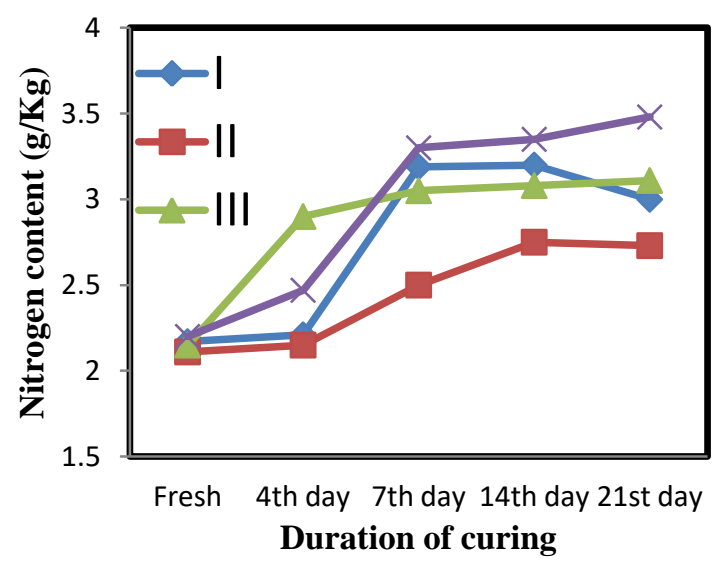

Figure2. The graph illustrated the total extractable nitrogen from control and experimental samples.

\subsection{Bacterial Count}

Determination of rate of degradation of skins by bacteria is one of the most important parameter that used for evaluating the efficiency of the preservation systems.

The bacteria population in experimental sample II was found as constant $\left(2.6 \times 10^{5}\right)$ on after 4 day compared to I $\left(2.8 \times 10^{5}\right)$. This clearly indicates the antibacterial effect of the ash salt prevented bacteria colonies from further growth during the interval of 4 days. A relative slower increased (10 $\%$ ) in the bacteria growth in II was seen from day 4 to day 7 against control (15.2\% increases) and also gradual increased by one fold in II is on 14 days. At the same time bacteria growth was found in 3 folds increase in control $(2.8$ $\mathrm{x} 10^{6}$ ); and later on growth started declining drastically in case II towards the end of 21 days (Table 3). This is due to the decreased in the moisture content in the skin.

In the case of experiment III, one fold growth (ie. $2.6 \mathrm{x}$ 105 from $2.4 \times 106)$ was measured during 4 days and then expansion $(18.8 \%)$ of bacteria count was observed from the day 4 to day 7 in comparison to control. On 14th days of preservation, there was increment by one fold (2.6 x 106) than I ( $2.8 \times 106)$.

This is because of gradual increased the removal of

moistures by III. The abnormal development was observed in experimental sample IV whereby colonies were in steady increased from fresh up to day 7. Then, slower decrement was noticed on 14th days and 21st day respectively but still showing the higher colonies in comparison to control and other experimental samples. This may be because of the combination may be reducing moisture slower and leaving the bacteria colonies intact. These results agreed with that of total nitrogen content of this present study.

Based on the results were reported in this study upon bacterial growth, the preservation potential of the preservatives were rated as: II $>$ I $($ control $)>$ III $>$ IV.

Table 3. Determination of Bacterial count (CFU in million/g of skin) on the preserved skins by control and experimental samples.

\begin{tabular}{llllll}
\hline Periods & \multicolumn{4}{l}{ Preserved Skins Used } \\
\cline { 2 - 6 } Fresh & $2.4 \times 10^{6}$ & II & III & & IV \\
& & & $10^{6}$ & & \\
& & & & \\
$4^{\text {th }}$ days & $2.8 \times 10^{5}$ & $2.6 \times 10^{5}$ & 2.6 & $\times$ & $2.9 \times 10^{6}$ \\
& & & $10^{5}$ & & \\
$\mathbf{7}^{\text {th }}$ days & $3.3 \times 10^{5}$ & $2.9 \times 10^{5}$ & 3.2 & $\times$ & $3.5 \times 10^{7}$ \\
& & & $10^{5}$ & & \\
$\mathbf{1 4}^{\text {th }}$ & $2.8 \times 10^{6}$ & $2.2 \times 10^{6}$ & 2.6 & $\times$ & $3.2 \times 10^{6}$ \\
days & & & $10^{6}$ & & \\
$\mathbf{2 1}^{\text {st }}$ & $2.3 \times 10^{6}$ & $1.8 \times 10^{6}$ & 2.6 & $\times$ & $3.1 \times 10^{6}$ \\
days & & & $10^{6}$ & & \\
\hline
\end{tabular}

Note: Values given are mean value of triplicate measurement

\subsection{Chemical Analyses of the Crust Upper Leather}

The determination of the chemical properties such as moisture content, oils/fats contents, ash content, etc. of the crust upper leather are the requirements of upper leathers. The chemical characteristics of the crust upper leather for the control and experimental study are given in Figure. 3. The results shown that the moisture content of II is higher compared to I (control). The fact is, the fibers of crust leather of II contained hydrophilic groups which were capable to absorb humidity from the surrounding and this enables leather to absorb perspiration, which is later, 


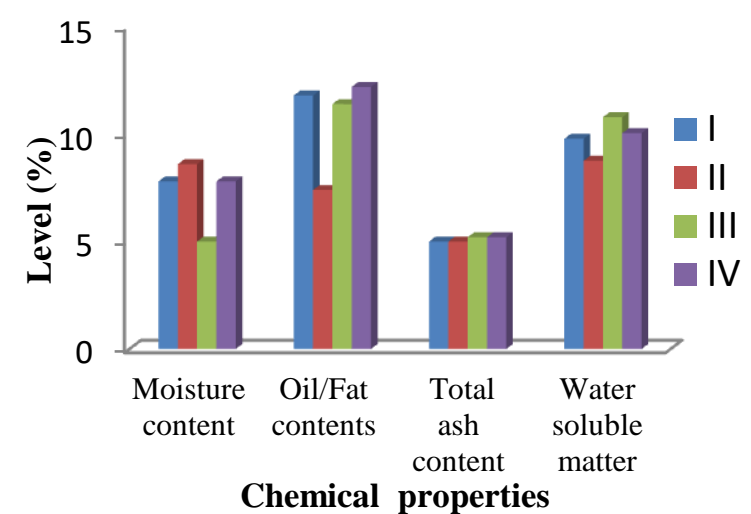

Figure 3. Chemical analyses of the crust upper leather of the preserved goat skin.

dissipated and is a significant factor in comfortness of leather [25]. In experiment (III), the moisture was less, this attributed to the present of more hydrophobic groups in the fibres of the leather whereas sample IV performed comparably to control.

The fat content of the crust leather II is less corresponded to control; this may be because the tanning method used might have slight effect on distribution or absorption of fats applied. Fat contents of III and IV were found statically comparable with I.

Total ash contents of the sample II, III and IV were found comparably. This may attribute to the similarity in crosslinking distribution of fibres of all cases of preserved skins.

Water soluble matters indicate the quantities of all those substances, which under certain conditions, are dissolved out of the leather by water. These are principally organic tannins, non-tannins and mineral salts. The lower the values of water soluble matter in leather, the higher the resistance to water soluble by leather and this was noticed in II compared to I.

In the case of III and IV, percentage water soluble matters were found to be statistically similar.

\subsection{Physical Characterizations}

The physical strength properties of the preserved chrome tanned leathers from the experimental study and control were analyzed and the results were tabulated in Table 4.

The tensile strength of the treated leather for experiments II, III and IV were $25.1 \mathrm{~N} / \mathrm{mm}^{2}, 21.8 \mathrm{~N} / \mathrm{mm}^{2}$, and 26.3 $\mathrm{N} / \mathrm{mm}^{2}$ respectively, corresponded to I (control) $24 \mathrm{~N} / \mathrm{mm}^{2}$.

Tensile strength of the exp.III was smaller and is corresponds to the less number of fibers or the quality of collagen present in the tanned leather. The values of elongation at break of experimental samples were as II (63.5 $\%)$, III (61\%) and for IV (60\%) compared to control, I $(63.3 \%)$. This is due to more interactions between chrome tanning agent and the collagen fibres of the leathers. That means no complicatedness occurred during leather processing. Good elongation at break may had also influence better elasticity and softness of leathers that observed in bulk properties (Figure 4.).
Table 4. Physico-mechanical Characterizations of crust goat leathers of controls and experimental study.

\begin{tabular}{|l|l|l|l|l|l|}
\hline \multirow{2}{*}{ Parameters } & \multicolumn{5}{|c|}{ Preservatives materials offered } \\
\cline { 2 - 6 } & I & II & III & IV & MR \\
\hline $\begin{array}{l}\text { Tensile } \\
\text { strength } \\
\left(\mathrm{N} / \mathrm{mm}^{2}\right)\end{array}$ & 24 & $\begin{array}{l}25 . \\
1\end{array}$ & 21.8 & $\begin{array}{l}26 . \\
3\end{array}$ & 12 \\
\hline $\begin{array}{l}\text { Elongation at } \\
\text { break (\%) }\end{array}$ & 63.3 & $\begin{array}{l}63 . \\
5\end{array}$ & 61 & 60 & $40-65$ \\
\hline $\begin{array}{l}\text { Tear strength } \\
(\mathrm{N} / \mathrm{mm})\end{array}$ & 49.9 & $\begin{array}{l}50 . \\
9\end{array}$ & 45.6 & $\begin{array}{l}48 . \\
9\end{array}$ & $20-50$ \\
\hline $\begin{array}{l}\text { Thickness } \\
(\mathrm{mm})\end{array}$ & 1.3 & 1.6 & 1.3 & 1.5 & 0.6 \\
\hline Note: Values given are mean value of triplicate
\end{tabular}
measurement

[MR = Minimum Requirement $]$

The values of tear strength of II, III, and IV were found to be comparable with control (I). The thickness of the skin does depend on the homogeneity or heterogeneity of the skin and it is the property that determines the usability of the end production of leather. The thickness of the treated leather samples II and IV were found to be thicker than the control (I). According to [26], a difference in thickness is due to the ability of tannins that can enhance the content of the skin and fill the empty spaces of the fiber network so that it becomes thicker.

\subsection{Thermal Stabilization of the Preserved Goat Leather}

The shrinkage temperature is a measurement of breakdown of stabilizing linkages existing in the collagen matrix, it helps to understand whether the new curing systems being tested have any effect on the destabilization of collagen matrix or not.

The experimental leathers tanned with basic chromium sulphate coded (II, III and IV) had the comparable shrinkage temperature of $103{ }^{0} \mathrm{C}, 99{ }^{0} \mathrm{C}$ and $95{ }^{0} \mathrm{C}$ respectively, compared to control $\left(105{ }^{0} \mathrm{C}\right)$.

Shrinkage temperature of all the experimental leathers were less and this was accounted to the effect of ash salt and table salt on each other during preservation which led to poor uniformity distribution of chromium tannin agents in the skin dermas that resulted into the decrease of thermal stability of the experimental leathers.

It was observed that the temperature value of each treatment decreased with the increased concentrations of $\mathrm{NaCl}$ in to ash salt (see Table.5). This may suggest that combination of preservatives does make sensible preservation effect on skin dermas.

Table 5. Shrinkage temperature of control and experiments preserved goat leather.

\begin{tabular}{lll}
\hline Sample code & $\begin{array}{l}\text { Shrinkage } \\
\left({ }^{\mathbf{C}} \mathbf{C}\right)\end{array}$ \\
\hline I (control) & 105 \\
II & 103 \\
III & 99 \\
IV & 95 \\
\hline
\end{tabular}




\subsection{Evaluation of Pollution Loads Generated in Soaking Liquors}

The pollution load generated in the soaking liquors of control and experimental samples were analyzed and the results were obtained are shown in Table.6. The results confirmed the substantially lower amounts of TS $(13.96 \pm 0.94)$ and TSS $(7.85 \pm 0.05)$ in sample II. This is may be due to the ash salt alone contained less chloride that may not make more pollution load than control and its combination.

There is also a noticeably lower load of TS and TSS in samples III and IV compared to control this is because of the less salt with combination of ash salt was used for preservation. The measured TDS in all the cases of experimental samples (II, III and IV) were drastically lower in the range $88.85 \pm 0.05-92.79 \pm 0.61 \mathrm{mg} / \mathrm{L}$ with sample II having sizeable lower TDS than others.

Much chloride $(112.58 \pm 0.78 \mathrm{mg} / \mathrm{L})$ was generated on soaked liquor, with table salt; whereas in the case of II, III and IV; soaked liquors were drastically lower chloride contents with about $67.8 \%, 64.8 \%$ and $62.2 \%$ lower chlorides discharges respectively. This clearly indicates that the ash salt may not consist of much chloride to influences on the discharges of soaked liquors.

Good ash salts are mainly rich in $\mathrm{KCl}$ and are rarely contain $\mathrm{NaCl}$, whereas certain ash salt substitutes do not have chloride at all but instead are shaped by potassium sulfate and carbonate [13].

The obtained values of COD and BOD from the experimental samples (II-IV) were attenuated alongside Ethiopia limits compared to control (Table.6). The results proved that the present studied ash salt preservation is considered as an alternative to conventional preservation method in a cleaner production and is feasible and reliable in leather technology.

Table 6. Pollution generated in the soaking liquors of preserved goat skins.

\begin{tabular}{lllllll}
\hline Parameters & I(Control) & Sample-II & Sample-III & Sample-IV & $\begin{array}{l}\text { Ethiopia } \\
\text { limits }\end{array}$ & Ref.No. \\
\hline TS (mgL) & $20.65 \pm 0.15$ & $13.96 \pm 0.94$ & $15.35 \pm 0.55$ & $17.95 \pm 0.65$ & N.A & \\
TSS (mgL) & $13.75 \pm 0.15$ & $7.85 \pm 0.05$ & $8.65 \pm 0.45$ & $10.80 \pm 0.70$ & $50 \mathrm{mg} L$ & {$[27]$} \\
TDS (mgL) & $189.43 \pm 0.88$ & $88.85 \pm 0.50$ & $89.69 \pm 0.50$ & $92.79 \pm 0.61$ & N.A & \\
Cl(mgL) & $112.58 \pm 0.78$ & $36.30 \pm 0.40$ & $39.62 \pm 0.48$ & $42.56 \pm 0.40$ & $1000 \mathrm{mgL}$ & {$[27]$} \\
$\operatorname{COD}(\mathrm{mg} \mathrm{L})$ & $25.64 \pm 0.54$ & $19.75 \pm 0.85$ & $19.92 \pm 0.88$ & $21.23 \pm 0.68$ & $500 \mathrm{mgL}$ & {$[27]$} \\
BOD (mgL) & $12.06 \pm 0.95$ & $7.60 \pm 0.10$ & $8.70 \pm 0.40$ & $9.08 \pm 0.70$ & $200 \mathrm{mgL}$ & {$[27]$} \\
\hline
\end{tabular}

Note: Values given are mean value of triplicate measurements. [N. A = Not Available]

\subsection{Characterization of Organoleptic Properties}

The rating of bulk properties of chrome tanned upper leathers for both experiments and control were measured and depicted in Figure 4.

It was observed that the experimental crust leathers (II, III and IV) exhibited better fullness than control (I) crust leather. This was because beam house operations had no any effect on fibres opening; as a result there were better absorptions of chromium Tannin agents; hence best qualities of leathers were obtained.

Control group displayed lower softness compared to experiments (II, III and IV). This may be due to poor absorption or distribution of oils/fats during fatliqouring by I.was so astringent. Hence, based on the result findings, the preserved-chrome tanned crust upper leather is rated as: II >

IV $>$ III $>$ I

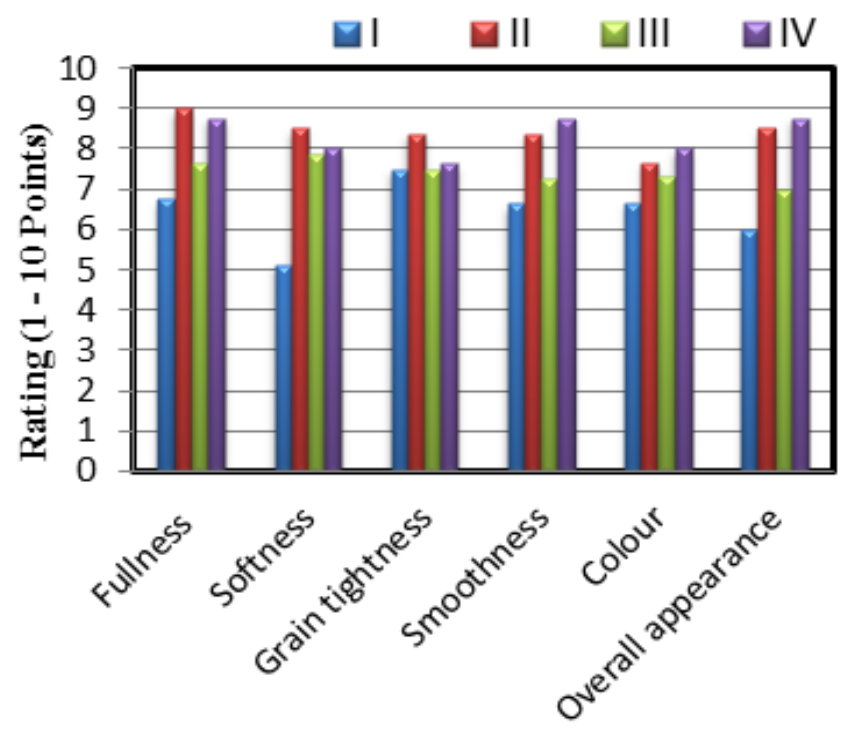

Bulk properrties

Figure 4. Organoleptic properties of crust upper leather for control and experiments of the preserved chrome tanned goat leather.

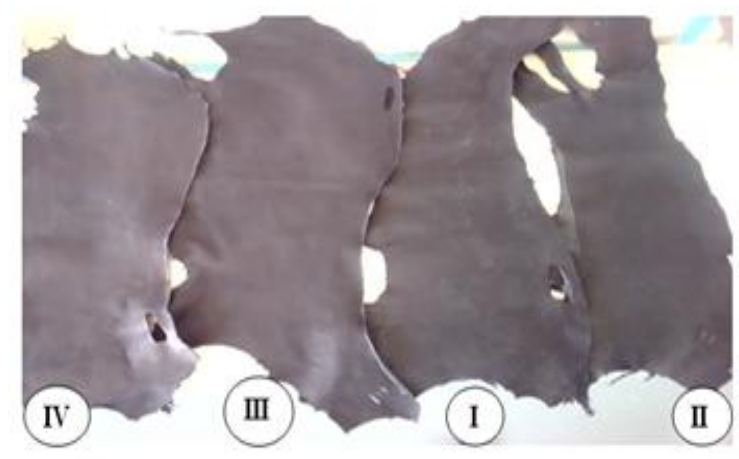

Figure5. The preserved-chrome tanned crust upper leathers with their respective codes.

\section{CONCLUSIONS}

Ash salt was derived from the ashes of Acacia albida and Acacia bussei and it was used as salt-less and less salt preservatives with intention to replace common salt curing system. Ash salt alone has demonstrated biocidic antibacterial effectiveness and therefore, is recommended to be use in leather industry alone as $\mathrm{NaCl}$ descendant because its fusions with $\mathrm{NaCl}$ has chemical effect on each other that resulted into slower moistures reduction and low Ts as well. Moisture contents of the preserved skins were reduced to less than $30 \%$. Hence, ash salt can preserve skins for more than a month even at lower concentration.

The shrinkage temperatures of experimental samples (IIIV) ranged from $95-103{ }^{\circ} \mathrm{C}$ compared to control $\left(105{ }^{\circ} \mathrm{C}\right)$. 
The main concerned among pollution loads in soaked liquor were TDS and $\mathrm{Cl}^{-}$; and they were found drastically lower than common salt.

\section{ACKNOWLEDGE}

The author appreciatively acknowledged Arba Minch University, Government of Ethiopia for providing financial support for the successful of the project. Mr. Franco J. Unango is also thankfully with University of Bahr el Ghazal, Government of South Sudan for surrendering him this rare opportunity to pursue his post graduate studies.

\section{REFERENCES}

1 Franco J., Ramesh D. and Karthikeyan R. "A review of eco-friendly preservative and bio-tannin materials using powdered barks of local plants for the processing of goatskin",International Research Journal of Science and Technology, 1, pp.13-20. 2019.

2 Covington A "Tanning Chemistry: The Science of Leather, Royal Society of Chemistry, Cambridge"p.72. 2009.

3 Kanagaraj J., Chandra B., Sadulla S., Suseela R., Visalakshi V. and Chandra K. "Cleaner Techniques for the Preservation of Raw Goat Skins", Journal of Cleaner Production, 9,pp.261-268. 2001

4 Daniels R. "Overview: Avoiding Salts", World Leather, 10, pp.41-45. 1997.

5 Kanagaraj J. and Chandra B. "Alternative to Salt Curing Techniques - A Review”, JSIR, 61, pp.339-348. 2002.

6 Shegaw A., Balaraman M., Berhanu A., Brindha V. and Alagumuthu T. "Rumex abyssinicus (mekmeko) Ethiopian plant material for preservation of goat skins: Approach for cleaner leather manufacture", Journal of Cleaner Production, 133, pp.1043-1052. 2016.

7 Vedaraman N., Sandhya K., Brindha V., Tamil S., Velappan K., John S., Kanagaraj J., and Muralidharan C. "De-oiled neem cake as potential bio-additive for lowsalt raw skin preservation: a process for salinity reduction in tanneries", International Journal Environmental Science Technology, 13, pp.1563-1572. 2016.

8 Madhan A., Abdul M. and Mehedi H. "Leaf Paste Aided Goat Skin Preservation: Significant Chloride Reduction in Tannery", Journal of Environmental Chemical Engineering, 6, pp. 4423-4428. 2018.

9 Sivabalan V. and Jayanthi A. "A Study To Reduce Salt Usage in Preservation of Skins and Hides with Alternate Use of Plant Extract", Journal of Agricultural and Biological Science, 4, pp.1990-6145. 2009.

10 Madhan A., Madhan N., Madhan H. and Mazharul I. "Sodium Chloride Substitute for Lower Salt Goat Skin Preservation: A Novel Approach, JALCA, 112, pp.270276. 2017

11 Vijayalakshmi K., Judith R. and Suseela R. "Novel plant based formulations for short term preservation of animal skins", Journal of Scientific and Industrial Research, 68, pp.699-707. 2009

12 .Jiacheng Wu., Li Zh., Xiong L., Wuyong C. and Haibin Gu. "Recent ProgressiIn Cleaner Preservation of Hides and Skins-Review", Journal of Cleaner Production, 148, pp.158-173. 2017.

13 Babayemi J., Dauba K. and Nwude D. "Evaluation of the Composition and Chemistry of Ash and Potash from Various Plant Materials-A Review", Journal of Applied Sciences, 10, p.1820-1832. 2010.

14 Tarkodjiel M., Mbaiguinam M., Ngaram N. and Mahmout Y. "Elemental Composition of Vegetable Salts from Ash of Four Common Plants Species from Chad",
International Journal of Pharmacology, 10, pp.18117775. 2012

15 Juan A., Oscar E. and Román J. "Witoto Ash Salts from the Amazon", Journal of Ethnopharmacology, 138, pp.492-502. 2011.

16 Shahruk M. and Nur A. "A Novel Method to Preserve Goat Skin with Indigenous Plant Extract to Reduce Chloride Load in the Effluent", Khulna-9203, Bangladesh, 150, pp.1234-1244. 2016.

17 BIS. "Methods of Test for Vegetable Tanning Materials", Doc: CHD17 (1627) C, ICS NO. 59.140.10. 2007.

18 Ilze G., Virgilijus V. and Justa S. "Raw Hide Preservation Using Vacuum under Low Temperature", $\mathrm{PhD}$. Thesis of a Case Study, Riga Technical University. 2015.

19 Guneet D. and Chakraborty J. "Antimicrobial Performance of Cotton Finished with Triclosan, Silver and Chitosan", National Institute of Technology, Jalandhar (144011), India, pp.2-10. 2015.

20 International Union for Physical Testing (IUP2). "Sampling", Journal Society Leather Technology Chemists 84, p.303. 2000a.

21 International Union of Leather Technologist and Chemist societies IUP/16: "Measurements of shrinkage temperature up to $100{ }^{\circ} \mathrm{C}$ ", Society of Leather Technologist and Chemists, p.21. 2001.

22 Official Methods of Analysis "Society of Leather Technologist and Chemists, UK. Grain", Journal of Stored Products Research, 49, pp.171-175. 1996.

23 Eaton A., Clesceri L. and Greenber A., "Standard Methods of the Examination of Water and wastewater, (20th ed.)", Washington, DC, American Pharmacists Association, p.278. 1995.

24 Philipa S. and Ahamed k. "Biological Factors Influencing the Nature of Goat skins and Leather", M.Sc. Thesis, a Case Study. 1994.

25 Ebtesam A. and Mohamed T. "Application of New Techniques by Using Local Tannage Material (Acacia Nilotica, Garad)", M.Sc. Thesis of a Case Study. 2007.

26 Untari, S., Viviana A and Bhiri F. "Intensive Program Ministry of Research and Technology", Center for Leather, Rubber and Plastics, (BBKKP), Yogyakarta, 33, pp.12-19. 2009

27 Abebe A. "REF. Corporate Environmental Responsibility in Ethiopia: A Case Study of the Akaki River Basin”, Technology, 13, pp.1563-1572. 2018. 